\title{
ACCOUNTING INFORMATION AND THE PREDICTION OF FARM VIABILITY
}

Author:

Name: Josep $M^{a}$ Argilés

University: Pompeu Fabra

ADDRESS:

Josep $\mathrm{M}^{\mathrm{a}}$ Argilés Bosch

Universitat Pompeu Fabra

Escola d'Estudis Empresarials

C. Ramon Trias Fargas 25-27

08005 Barcelona

Phone: (93) 5422405

Fax.: $\quad$ (93) 5422296

(93) 5422366

e-mail: josep.argiles@econ.upf.es

RUNNING TITLE: ACCOUNTING AND PREDICTION OF FARM VIABILITY

We acknowledge the help of the "Xarxa Comptable Agrària de Catalunya", who provided us with the data that made this paper possible. 


\title{
ACCOUNTING INFORMATION AND THE PREDICTION OF FARM VIABILITY
}

\begin{abstract}
:
Farms make little use of accounting and until now have been largely excluded from the scope of accounting standards. However, we hypothesize that the use of accounting-based information can significantly improve the explanation and prediction of farm viability/failure. Two dichotomous logit models were applied to subsamples of viable and unviable farms in Catalonia, Spain. One model included non-accounting-based variables, while the other also considered accounting-based variables. It was found that, when accounting variables were added to the model there was a significant reduction in deviance.
\end{abstract}

Keywords: accounting, agriculture, failure prediction, farm viability 
¡Error! Argumento de modificador desconocido. 


\section{ACCOUNTING INFORMATION AND THE PREDICTION OF FARM VIABILITY}

\section{INTRODUCTION}

This paper examines the utility and importance of using accounting information for predicting farm viability.

Any firm or entity whatever will require accounting information. This should cause no raised eyebrows and no-one presumably finds the proposition contentious. Particularly in agriculture, it is generally assumed that the introduction of accounting will improve farm management and produce better farm performance (see for example Luening, 1989). However, Poppe (1991) regrets that no research has yet been able to demonstrate this, and has reported the limited use of accounting in agriculture. Moreover, To the author's knowledge there is no published empirical research as to whether the use of accounting data can significantly improve the explanation and prediction of farm viability/failure.

Olsson (1988) and Allen (1994) explain this limited use o accounting in agriculture by the lack of accounting skills by farmers, considering the predominance of the small family farm even in the agricultural production of highly industrialized Western countries (Schmitt, 1991). Poppe (1991) and Poppe and Breembroek (1992) also propose a number of other explanations. Kroll (1987) and André (1987) point out that when French farmers use accounts, it is mainly to comply with tax and subsidy requirements. Sabaté and Enciso (1997) make similar observations for Spain. Colwell and Koroluk (1990) state that an informal cash bookkeeping system is the most common accounting method used in Canada in spite of the fact that this does not indicate the true performance of the farm. Seger and Lins (1986) report similar findings in the USA. Bronstien (1995) and Crane and Leatham (1995) regard standardized accrual accounting and record keeping as necessary for the development of agricultural business in the USA. In France and the European Union (EU) tax related and economic motives encourage authorities to promote the use of accounting in agriculture (Pellerin, 1985).

The limited use of accounting in agriculture could lead to think that it is not useful for decision-making. This article aims to provide empirical evidence that accounting makes a significant contribution to explaining and predicting farm viability. We believe that this evidence reveals both the need for increased use of accounting in agriculture and for the development of accounting standards for agriculture.

Our research makes use of failure prediction models. Existing literature on these models and research into farm viability served as the starting point for our study.

The following section provides background information about farm viability and failure prediction models. We then discuss research method, defining "failure event", describing the independent variables, the logistic regression employed, the development of hypotheses and sample characteristics. We then detail our results and present conclusions. 


\section{BACKGROUND}

A voluminous literature on failure prediction models has been developed since Beaver (1966) and Altman's (1968) seminal studies.

Research into failure prediction in agriculture is comparatively scarce. To the author's knowledge the earliest empirical studies in this area began with Reinsel and Brake (1966). Krause and Williams (1971), Bauer and Jordan (1971), Johnson and Hagan (1973) and Dunn and Frey (1976) used discriminant models to assess farm loan repayment. These studies were undertaken at a time in which the indebtedness of US farms was increasing and this was more and more difficult to manage (Murdock and Leistritz, 1988, p. xiii). The subsequent agricultural crisis and high incidence of farm and agricultural bank failures, coupled with unexpected losses by agencies providing loans to farmers during the mid 1980s, stimulated new research (Ibid.). Shepard and Collins (1982) explained farm failure at the macroeconomic level, while Grisley (1985), Griffis (1988) and Lins et al. (1987) measured the financial health of farms.

Subsequent research into attempts to cope with the financial crisis of US farms involving explicative or prediction models can be classified in three groups. Some analysts focused on the economic viability of farms: Kauffman and Tauer (1986) and Smale et al. (1986) used binomial logit models to do this, while Adelaja and Rose (1988) used a simultaneous-equation model. Another group used multinomial logit models (Lines and Zulauf, 1985), ordered logit models (Lines and Morehart, 1987; and Wadsworth and Bravo-Ureta, 1992) and a multiresponse ordered model (Carley and Fletcher, 1988) to explain and predict various degrees of financial health. The third group, from which we highlight the work of Mortensen et al. (1988), Turvey and Brown (1990) and Knopf and Schoney (1993), used binomial logit models to predict farm loan repayment. In the same group, Turvey (1991) compared the predictive accuracy of the linear probability model, discriminant analysis, logit and probit.

All these, with the exception of the last three references, were carried out in the USA, and to the best of our knowledge few of such studies have been conducted elsewhere. We also know of some research in this field in the EU. Colson and Pineau (1991) and Colson et al. (1994) made descriptive studies of financial stress on French farms. Harrison and Tranter (1989) described the evolution of the financial structure of farms in the United Kingdom during the 80s. Crabtree (1985) studied farm viability in Scotland using a simple regression model. Brangeon et al. (1994) used a logit model to explain persistent farm losses in France.

Krause and Williams (1971), aware of the difficulties in obtaining accurate accounting data with which to evaluate loan repayments, used easily employable personality indicators.

Pederson and Donovan (1990) found that more sophisticated financial loan evaluation tools, in which accounting information was taken into account, were associated with lower loan delinquency, and that such practices, when possible, were preferred by agricultural banks. 


\section{RESEARCH METHOD}

\section{The viability/failure event}

Altman (1993) pointed out that failure, insolvency, default and bankruptcy are common terms used in literature on financial distress to refer to unsuccessful business. Jones (1987) reviewed the problems involved in defining the dependent variable in financial distress models. Wide range of different dependent variables has been used in the literature on failure prediction models (Rodríguez-Vilariño, 1994a).

In agriculture it is difficult to accurately estimate the number of failed farms (Davies, 1996). Before failure occurs farmers tend to emigrate or take up off-farm employment (San Juan, 1994, p. 337), and so failure is a very delated process (Colson and Pineau, 1991; and Jolly et al. 1985). Rather than failure, retirement (Fennell, 1993, p. 48) and renouncing parent's farm (Poppe and Zachariasse, 1986, p. 374) are the main reasons for the decline in number of farms and farmers, whereas officially, failure rates are comparatively very low in agriculture (Brangeon et al., 1994).

Leistritz and Ekstrom (in Murdock and Leistritz, 1988) showed that a comparatively large variety of approaches to farm failure can be found in studies applied to agriculture.

We consider punctual repayment of scheduled loans (used by Reinsel and Brake, 1966) and credit ratings on good and problem loans (used by Johnson and Hagan, 1973; Bauer and Jordan, 1971; Knopf and Schoney, 1993; Turvey and Brown, 1990 and Mortensen et al. 1988) to be ambiguous and subjective. Similarly, changes in net worth (used by Krause and Williams, 1971) also seem to provide an unsatisfactory measure of financial success. Debt-toasset ratio (Lines and Zulauf, 1985) and positional categories of financial health (Melichar, 1985; Wadsworth and Bravo-Ureta, 1992; and Carley and Flechter, 1988) also seem arbitrary and partial measures. Seger and Lins (1986), Ofek (1993) and Phimister (1995) point out that cash flow generation, used by Grisley (1985) and Adelaja and Rose (1988), is a particularly misleading indicator in agriculture. The viability ratios of Smale et al. (1986) have the inconvenience that they use data of a single-year and require data which are not available at our data source.

Their reliance on single-year data is one of the weaknesses of the previously mentioned studies. It has been known for many years that single-year data show a marked variability, because farm activity suffers from very pronounced random effects (King, 1927; and Milhau, 1961). We defined our dependent variable over the maximum period available for our Spanish sample-data. Research by Cordts et al. (1984) and the European Commission (1991a, p. 84) found that income variability tends to be significantly reduced when a three-years period is considered.

We followed the approach of Brangeon et al. (1994) and The European Commission (1991b), which consider viability in a wider sense, as the ability of an enterprise to exist on a profitable basis over a long period. Following the Council regulation (EEC) 2328/91 of 15 July 1991, we believe that a clear cut off exists between farms where profitability is great enough to remunerate the working time put in by the family at a comparable regional wage and those in which profitability is not great enough. In the long term, when job opportunity exist, farmers of these last farms will leave farming. Identifying those of such farms that may be helped towards viability was an important goal 
of the Common Agricultural Policy (CAP) in the past (European Commission, 1994a, p. 53). And it seems to be important in the immediate future in the EU. Further rounds of the International Trade Organization, after 2000, and future reforms of the CAP to accommodate new EU members from Eastern and Central Europe, will lead to adapt farms of the EU to the conditions of a freer world market (Sumpsi, 1995). Some existing farms will need to modernize rapidly or face ruin.

Even though the capacity to predict viable and unviable farms may not be relevant for farm management, it is important for other agents involved in agriculture. For example, banks evaluating farm loan repayment or policymakers planning policies or grants to make farms viable. Moreover, inefficient farm behavior under risk of failure (Foster and Rauser, 1991) could be avoided when farms would be helped towards viability.

We started from the definition of farm viability employed by the European Commission (1991b). We think that we improved it, because we avoided the subjective combinations of work and capital remuneration employed in it.

We defined a dichotomous dependent variable $Y$ according to the following equation:

$$
\gamma_{i}=\sum_{h=1}^{h=m}\left(F F I_{i h}-F W U_{i h} x I R_{h}\right)
$$

where, following to the methodology of the Farm Accountancy Data Network (FADN), $F F I_{i h}$ and $F W U_{i h}$ respectively represent family farm income and family work unit of farm $i$ in year $h . I R_{h}$ is the income of reference for year $h$. The Spanish Ministry of Agriculture states the income of reference as the gross annual wage of non agricultural workers. This means the income that farmers could obtain in alternative jobs. $\gamma_{i}$ is the farmer's net income after remunerating his work. Given the questions discussed above, we decided to convert the interesting data of equation (1) to a dichotomous variable. When $\gamma_{i} \geq 0$ then $Y_{i}=0$ indicating that $i$ is a viable farm. On the contrary, when $\gamma_{i}<0$ then $Y_{i}=1$ indicates that over a long period $i$ is a distressed farm.

\section{Independent variables}

In the first stage of our analysis we considered two groups of variables: structural and financial variables.

Two kinds of variables are usually employed in predicting farm failure: financial ratios and any other variables taken from accounting information and variables relating to characteristics of specific farm and farmers that do not meet an accounting criteria, but are easily observed and usually reflect structural and fixed characteristics of each particular farm. We also distinguish two kinds of variables. On the one hand, accounting variables are usually difficult to obtain from farms because they require accounting procedures. As previously mentioned, the use of accounting in agriculture is generally limited. On the other hand, structural variables can be obtained more easily because accounting procedures are not needed. The latter describe the structure of these farms and include such factors as farm output, acreage, livestock units, age's operator, etc. 
The first criteria used for selecting variables was their theoretical importance and the existence of a prior consistent economic relationship with the dependent variable. We reviewed the most frequently used variables in previous studies, as shown in the ranking made by Laffarga and Pina (1995) based on a review of 27 famous researches. We reviewed 21 articles to obtain a ranking of the variables most commonly used in studies applied to agriculture and found that each of the following occurred more than four times: debt-to-asset ratio, dichotomous variables relating to the region in which the farm was located and its production, the number of people forming the household, the age of the farmer, and the ratio of current assets to current liabilities. However, for the purposes of our study it was not possible to obtain data for all of these variables.

Table 1 lists and describes the variables which we used as the basis of our analysis.

(table 1)

$E S U, U A A, L U$ and $A W U$ are measures of farm size. It is expected that the greater the size of the farm, the smaller the probability of failure. Big farms usually perform better than small (European Commission, 1991a; and European Commission, 1993b). However, empirical evidence is not unanimous. For example, while Reinsel and Brake (1966) and Adelaja and Rose (1988) found that the greater utilized agricultural area (UAA) of the farm was associated with a smaller probability of loan repayments problems, Dunn and Frey (1976) found the inverse relation.

$A G E$ is an indicator of experience. It is generally expected that the younger the farmer the greater the probability of failure. Carley and Flechter (1988) and Lines and Zulauf (1985) found empirical evidence of it. However, Wadsworth and Bravo-Ureta (1992) and Brangeon et al. (1994) found a threshold of age where the probability of failure is the slowest and then increases.

$F W U / A W U$ is an indicator of professionalism and is related to farm size. It is expected a positive relation with de dependent variable. The European Commission (1991a) found a better performance in the group of farms with a low share of total labour input coming from family labour.

OUTPUT/AWU and OUTPUT/E are measures of productivity. It is expected that the more productive farms, measured as high values in output to annual work unit or to economic size unit, will have a smaller probability of failure. Wadsworth and Bravo-Ureta (1992) and Carley and Flechter (1988) found this relation employing physical measures of productivity.

OUTPUTCO indicates the degree of product diversification of the farm. A moderate degree of diversification is expected to be associated with viability. This was partly found by Lines and Morehart (1987). Ehrenfeld (1987) confirmed also this relation. However, Kauffman and Tauer (1986) did not found a strong relation with diversification and farm success.

LIVESTOC, IRR and NIRR are dummy variables that identify the predominant style of farming. It is expected that the predominance of dry farming crops in the total crops (NIRR) increase the probability of failure. Dry weather and water shortages handicap farming in Mediterranean countries. The opposite relation is expected for the other variables. Previous studies used different variables of classifications of crops based on the data available to them. 
NORMALZO, LESSFAZO and MOUNTZO refer to different types of farm location. It is expected that farms located in less favoured and mountain zones will have a big probability of failure, and the opposite for those located in normal zones. The European Commission (1994b) found better performance for these last farms than for the other.

$D / A, C L / C A, N W / F I X A, P L I N / O$ and DEBT/FFID are indicators of financial status. It is expected that the more the indebtedness or the financial burdens of the farm, the larger the probability of failure. Shepard and Collins (1982) argue that the increased use of borrowed capitals makes farms more vulnerable to year-to year shortfalls in income, facing increased risk of failure. The signs in table I show this relation. The definition of some of these variables have been modified to meet the needs and the availability of data of our study. $D / A, C L / C A$ and $D E B T / F F I D$ are between the most classical and frequently used variables in failure prediction models. Crabtree (1985), Davies (1996) and the European Commission (1991a) found that PLIN/O was significantly related with farm viability and performance.

TOEXP/AS is a measure of the expenses of the farm. It is expected that farms saving costs will be more viable. Ehrenfeld (1987) argued that farms with low percent of costs to assets (TOEXP/AS) had a small probability of bankruptcy.

We hypothesize that efficiency in assets use, measured by turnover of assets (OU/AEXL) and return on assets (FFILI/TA) affects viability positively. It is expected a negative relation between these ratios and the dependent variable. Turvey (1991), Turvey and Brown (1990) and Knopf and Schoney (1992) found that a high value for return on assets was significantly associated with successful loan repayment.

\section{The logistic regression}

Altman's (1968) seminal study used linear discriminant analysis. The biggest problem with this type of analysis is that it requires that explanatory variables for both groups proceed from normal populations and the same covariance matrix (Maddala, 1989, pag. 18). If this is not the case, the estimators are not consistent (Gordon and Arun, 1987).

Some of the problems deriving from unequal covariance matrices could be solved by using a quadratic, rather than a linear, discriminant model, but this can affect classification performance. Altman et al. (1977) found lower classification accuracy when using quadratic discrimant analysis, especially with the holdout sample. Furthermore, financial ratios and accounting variables usually present non-normal distributions (Jacky, 1987; and Rodríguez-Vilariño, 1994b), and as Press and Wilson (1978) pointed out, the introduction of dummy variables automatically violates the assumption of normality.

Lo (1986) showed that the logit probability model is more robust than discriminant analysis in the estimation of parameters and that it is valid under more general distributional assumptions for independent variables. Jones (1987) concluded that logit models may be slightly more accurate, and certainly no less accurate, than discriminant analysis models.

An alternative to logit are probit and recursive partitioning, but the former presents significant computational problems (Altman et al. 1981). Recursive partitioning was introduced in failure prediction by Frydman 
et al. (1985). Recursive partitioning does not require the assumptions of normality and an equal covariance matrix, but it fails to offer any estimation of classification probability and using this model it is difficult to ascertain the relative importance and significance of the independent variables (Altman, 1993; Jones, 1987; and RodríguezVilariño, 1994b).

Since Martin (1977) and Ohlson (1980) logistic regression has been increasingly used in bankruptcy prediction and since this time logit models have dominated failure studies.

Our research was primarily designed to detect incremental improvements in the predictive and explanatory power of accounting information in agriculture. Thus, our chief criterion was that the model tested should be unbiasedly capable of predicting corporate failure. Given this goal and the questions discussed above, we decided to use logistic regression.

The dichotomous logit model assumes a logistic cumulative distribution function in the form (Greene 1993)

$$
P(i)=\frac{1}{1+e^{-\beta x(i)}}
$$

where $P(i)$ is the probability of farm $i$ suffering distress or being unviable, $(1-P(i))$ is the probability of being viable, $x(i)$ is a vector of the measured attributes of the firm, and $\beta$ is a vector of unknown parameters to be estimated.

\section{Development of hypothesis}

To test our assertion that accounting provides significant information to predict farm viability we require the best selection of structural variables to predict farm viability. On the other hand we require the best selection of accounting variable to do the prediction.

Wald forward stepwise selection procedures based on variables from table I provided two logit models. One comprising only structural variables and the other with both, structural and accounting, variables.

To test for incremental difference in predictive and explanatory power we examined the reduction in deviance caused by the introduction of accounting variables. A full explanation of this test can be found in Norussis and SPSS (1990). This test was used in similar way to ours by Richardson et al. (1998) to test recession impact on corporate failure. The formula for the test statistic is

$$
\lambda\left(\beta_{1} / \beta_{2}\right)=2 \ln L(\beta)-2 \ln L\left(\beta_{2}\right)
$$

where $\lambda\left(\beta_{1} / \beta_{2}\right)$ is defined as the change in deviance between the full model of structural and financial variables, labeled $\beta$, and the reduced model of only structural variables (i.e., the contribution of the additional accounting variable set $\beta_{I}$ ), and $L$ is the maximum likelihood estimator for the indicated models. The statistic has an approximate chi-square distribution with $k$ degrees of freedom, where $k$ is the incremental difference in parameters between any two models. 
The change in deviance described by the equation (3) was also used to test goodness-of-fit. In this case, the reduced model included only the intercept term while the full model included the intercept together with the independent variables used in our prediction model. The resulting change in $-2 \ln L$ was then used to test the joint significance of the explanatory variables, also with an approximate chi-square distribution with $k$ degrees of freedom indicating the number of independent variables. The term $-2 \ln L$ is the algorithm of the maximum likelihood estimator. In addition, goodness-of-fit was ascertained by employing $Z^{2}$ statistic provided by SPSS 4.0 package and defined as follows

$$
Z^{2}=\sum_{i=1}^{i=N} \frac{\left(Y_{i}-P_{i}\right)^{2}}{P_{i}\left(1-P_{i}\right)}
$$

where $Y_{i}$ and $P_{i}$ are the observed and predicted values. This statistic tests the null hypothesis that the model fits perfectly and also has a chi-square distribution with approximately $N$ - $p$ degrees of freedom, where $N$ is the number of cases and $p$ the number of parameters estimated (Norussis and SPSS, 1990).

\section{Sample}

The FADN provides annual statistics on the state of agriculture in the EU based on a sample of almost 60.000 EU farms. Data are collected by surveying a rotating sample of farms. The FADN field of observation covers professional farms as defined in the farm structure survey of the EU, and excludes smaller farms below FADN thresholds. A full description of FADN procedures and methodology can be found in European Commission (1988a; 1988b; and 1990). FADN methodology differs in some aspects from generally accepted accounting principles (GAAP) presently in force in the IAS, and from the Draft Statement of Principles issued by the SCA of the IASC (IASC, 1996). In fact, FADN does not seek to follow the GAAP. It aims to provide a rich source of microeconomic data for the development of the CAP (European Commission, 1991a, p. 1). However, it is "in a certain sense itself a standard setting body" (Poppe and Beers, 1996, p. 18). All data of farms in FADN are tested and follow the same methodology and accounting standards. FADN provides the most adequate available data that we need for our study.

FADN statistics are regularly published, but the individual farm data necessary for our study are not generally available.

The "Xarxa Comptable Agrària de Catalunya" (XCAC) is the subsidiary of the FADN in Catalonia, Spain, and follows its methodology. The XCAC provided us with data relating to the performance of 82 individual Catalan farms over 1989, 1990 and 1991. We subsequently obtained a subsample of 19 viable and 63 distressed farms for the period considered. We believe that the population studied exhibited a similar distribution of frequencies between viable and distressed farms because this both states were randomly obtained from the overall sample. The proportions were also very similar to those obtained by the European Commission (1991b). This helped us to avoid some of the methodological flaws that appear when non-random equal-share samples are used in binary state prediction models (Palepu, 1986). 
The characteristics of the sample are presented in tables 2 and 3. The independent variables correspond to values for the year 1989, while the dependent variable is derived from applying data from the years 1989, 1990 and 1991 to equation (1).

We used SPSS 4.0 for data processing.

(tables 2 and 3)

\section{EMPIRICAL RESULTS}

An automatic forward stepwise wald procedure run with structural variables selected the following variables: FWU/AWU, OUTPUT/E and NIRR. We call the model composed by these variables "structural model". It only includes these variables because attempts to add more variables failed to provide any significant improvement to goodness-of-fit. The estimated logit parameters and goodness-of-fit are presented in table 4 as can be seen. The model presents a significant goodness-of-fit.

(table 4)

Virtually all parameters of the variables are significantly different from zero at the $5 \%$ confidence level while the constant term is not. The signs on the parameters conformed to our expectations. Higher values for family work unit per annual work unit $(F W U / A W U)$ were associated with increased probability of farm failure. higher values in the ratio output to economic size unit (OUTPUT/E) gave higher probability of farm viability. The predominance of dry farming crops in the total output (NIRR) increased the probability of failure.

Table 5 shows the accuracy of predictions. The model obtained a score of $79 \%$ accuracy in classification, which is greater than that provided by a random procedure. However, accuracy was very low for the sub-sample of viable farms.

(table 5)

A second automatic forward stepwise wald procedure run with all variables in table I selected the following variables: UAA, FFILI/TA, OU/AEXL and FWU/AWU. They compose what we called our "accounting model". As occurred with the structural model, attempts to add more variables provided no significant additional goodness-of-fit.

Table 4 also shows the estimated logit parameters and goodness-of-fit. As can be seen, the model presents a significant statistical fit.

Again, all parameters of the variables were significantly different from zero at the $5 \%$ confidence level while the constant term was not. The signs on the parameters conformed to our expectations. The greater the utilized agricultural area $(U A A)$ of the farm, the smaller the probability of failure. Wald parameters for this model (see table 4) 
show that return on assets (FFILI/TA) was the variable that most contributed to the model. This is the first approach to point out the importance of accounting information. We therefore hypothesized that efficiency in asset use (OU/AEXL) positively affects viability positively, a fact which is confirmed by the negative sign of the coefficient. Finally, expectations about family work unit per annual work unit ( $F W U / A W U$ ) were also significantly confirmed, showing that the more professionalized the farm, the more probability of being viable.

The accounting model significantly improved the accuracy of prediction of the structural model, especially in the sub-sample of viable farms, as seen in table 5.

The structural model provided the best significant goodness-of-fit that could be obtained from the pool of structural variables initially considered. The same was true for the "accounting model" with respect to all structural and accounting variables.

To test whether the accounting model has more significant goodness-of-fit than the structural model we built a third model incorporating all variables included in the structural and accounting models. We had to use this third reference model because not all variables included in the structural model were present in the accounting model.

The Chi-square test statistic $\lambda$ was 28,626 ( $3 \mathrm{df}$ ) for the difference in $-2 \ln L$ for the structural and the third models, an amount that is statistically significant with $\mathrm{p}<0,01$. Thus, the third model significantly improved the explanation and prediction of farm failure. Comparing the accounting and third models, the $\lambda$ was 0,763 ( $2 \mathrm{df}$ ) for the difference in $-2 \ln L$, which is neither statistically significant with $\mathrm{p}<0,01$, nor with $\mathrm{p}<0,1$. Thus, the third model did not significantly improve the accounting model. We conclude that the accounting model significantly improved the structural model when explaining and predicting farm viability. That is, accounting offers significant incremental information for management and all other factors relating to farm viability. Therefore, in addition to farmers, agents such as banks, policymakers, public institutions and insurance companies should also take decisions based on relevant information provided by accounting data.

\section{SUMMARY AND CONCLUSIONS}

There are few works on the use of accounting in agriculture. Moreover, to the best of author's knowledge no empirical study has previously tested either the relationship between keeping accounting records and farm results, or the contribution accounting can make to predict farm viability.

We started by studying the large bibliography of existing research into failure prediction and the relatively limited number of these works which have been applied to agriculture. We defined farm viability as the ability to remunerate the working time put in by the family at a comparable wage over a long period. A reduction in deviance test was applied in order to compare two logit models. The first represented the best model built with a selected set of structural variables to explain and predict farm viability, and the second represented the best model built with structural and accounting variables. The test confirmed our hypothesis about the significant incremental value of information provided by accounting. 
The share of total labour input coming from family labour, utilized agricultural area, return on assets and turnover of assets except land provide a significant model to explain and predict farm failure.

Unfortunately, we could not find a holdout sample for supporting our conclusions.

There are some reasons to explain the use low of accounting by farms. However, we concluded that accounting-based information is an important tool for assessing farm viability. Policymakers and agents involved in agriculture will get greater efficiency and effectiveness in their decisions when they base them in accounting-based information of the farms. For example, banks evaluating farm loan repayment or policymakers planning policies or grants to make farms viable, as mentioned previously.

We do not know whether the farms of our sample used accounting information for their decision-making. Furthermore, we do not know the degree to which such information may have been used by them. Consequently, it was not possible to test the relationship between the use of accounting and farm performance. However, we could assume that when this incremental information existed, consequent corrective or preventive actions could be advantageously undertaken.

Authorities and institutions should therefore promote the use of accounting in agriculture, helping to solve technical and cost inconveniences for farmers. Even so, appropriate accounting standards are a necessary precondition for any such developments.

Table 1. List of independent variables considered;Error! No se encuentra la fuente de la referencia.

VARIABLE EXPECTED SIGN

\section{Structural variables}

ESU

UAA

LU

AWU

AGE

FWU/AWU

OUTPUT/AWU

OUTPUT/E

OUTPUTCO

LIVESTOCK

IRR

NIRR

NORMALZO

LESSFAZO

MOUNTZO

\section{DESCRIPTION}

Economic size units (in European size units).

Utilized agricultural area.

Livestock units (in standard units).

Labour units (in annual work units).

Age of the farmer.

Family work unit to annual work unit (in a per one basis).

Total output to annual work unit (in ecus).

Total output to economic size units (in ecus).

Herfindall output concentration measure.

Predominance of livestock in total output.

Predominance of crops typically grown on irrigated land in total output.

Predominance of crops for dry farming in total output.

Location in normal zone.

Location in less favoured zone.

Location in mountain zone. 


\section{Financial variables}

$\mathrm{D} / \mathrm{A}$

CL/CA

NW/FIXA

PLIN/O

DEBT/FFID

TOEXP/AS

OU/AEXL

FFILI/TA
$(+)$

$(+)$

$(-)$

$(+)$

$(+)$

$(-)$
Debt-to-assets ratio.

Current liabilities to current assets.

Net worth to fixed assets.

Percent of leases and financial charges to total output.

Percent of debt to family farm income plus depreciation.

Total expenses to total assets.

Turnover of assets: output to assets except land (in ecus).

Return on assets: family farm income less financial charges and taxes to total assets. 
Table 2. Descriptive statistics for quantitative independent variables in the sample

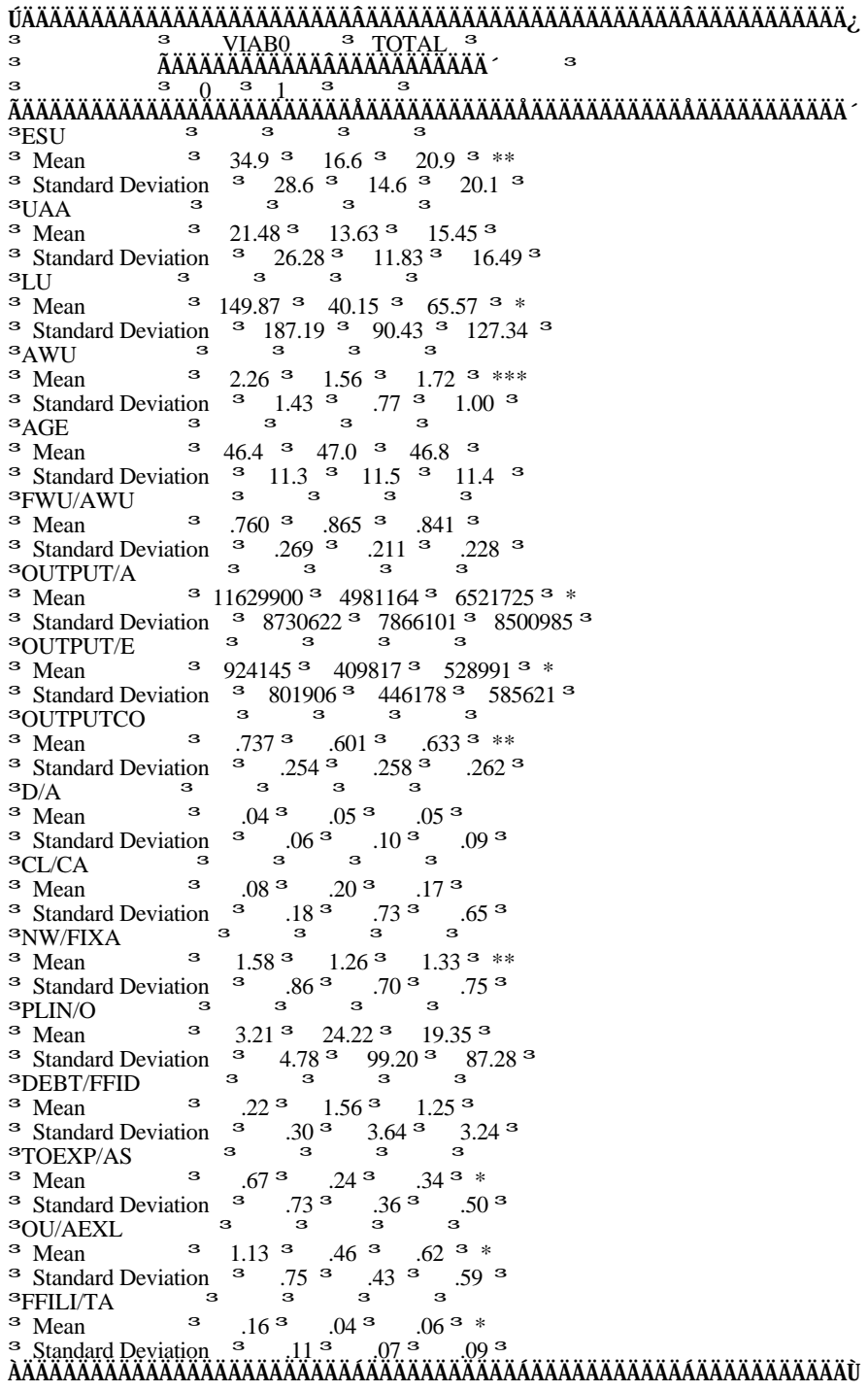

Notes:

VIAB0 takes the following values: 0 for viable farms and 1 for failed farms. Found significant differences with $\mathrm{p}<0,01(*), \mathrm{p}<0,05(* *)$ and $\mathrm{p}<0,1(* * *)$ 
Table 3. Descriptive statistics for categorical independent variables in the sample

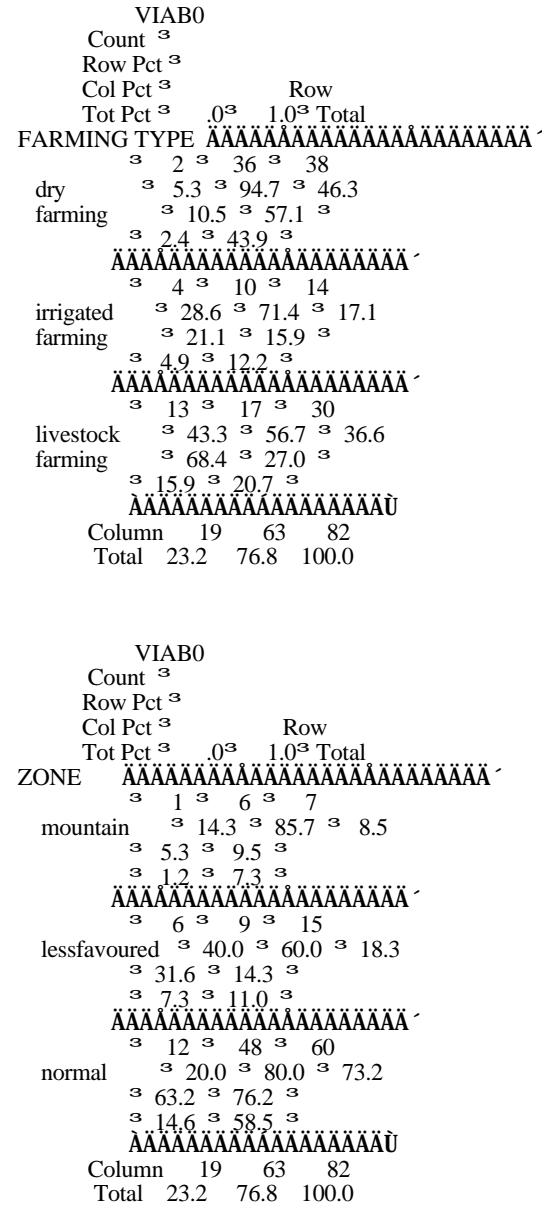

VIAB0 takes the following values: 0 for viable farms and 1 for failed farms. Found significant differences with $\mathrm{p}<0,01(*), \mathrm{p}<0,05(* *), \mathrm{p}<0,1(* * *)$. 
Table 4. Estimated logistic models and goodness of fit statistics

$$
\text { Structural model }
$$

Variables

Constant

OUTPUT/E

NIRR

UAA

Goodness of fit

-2 Log Likelihood

$\mathrm{Z}^{2}$ Ruction in deviance

\begin{tabular}{llll}
\multicolumn{1}{c}{ Coeff. } & & Wald & Signif. \\
$-2,3107$ & & 3,1742 & 0,0748 \\
4,3553 & & 8,2223 & 0,0041 \\
$-1,2 \mathrm{E}-06$ & 4,7468 & 0,0294 & \\
2,6156 & & 6,5346 & 0,0106
\end{tabular}

Chi-Squarre

62,131
26,647
64,000

Signi
78
3
78

0,9056
0,0000
0,8732

Accounting model

Full (Third) model

\begin{tabular}{|c|c|}
\hline Coeff. & Signif. \\
\hline $\begin{array}{l}1,2148 \\
6,7729\end{array}$ & 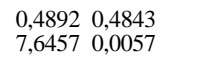 \\
\hline $\begin{array}{l}-0,0554 \\
-26,4555\end{array}$ & $\begin{array}{r}4,8022 \quad 0,0284 \\
11,9691 \\
0,0005\end{array}$ \\
\hline
\end{tabular}
Coeff. Wald
Signif.
$\begin{array}{lll}1,3835 & 0,3980 & 0,528\end{array}$
$\begin{array}{llll}-9,1 \mathrm{E}-07 & 0,6618 & 0,4159\end{array}$
$\begin{array}{rrrr}-9,-0,1353 & 0,6618 & 0,4159 \\ -0,069 & 0,0085 & 0,9265\end{array}$
$\begin{array}{cccc}-0,0609 & 4,0767 & 0,0435 & 0,008 \\ -25,9500 & 11,0061 & 0,0009\end{array}$

$\begin{array}{ccccc}-2,4944 & -26,4555 & 11,9691 & 0,0085 & 0,0005\end{array}-2,070$

$$
2,5423 \quad 0,1108
$$

$\begin{array}{rrr}\text { Chi-Squarre df } & \text { Signif. } & \text { Chi-Squarre } \\ 34,268 & 77 & 1,0000 \\ 54,510 & 4 & 0,0000 \\ 65,161 & 77 & 0,8298\end{array}$

Signif.
33,505
55,273
62,525

$\begin{array}{ll}75 & 1,0000 \\ 6 & 0,0000 \\ 75 & 0,8475\end{array}$

0,0000

¡Error! Argumento de modificador desconocido. 
Table 5. Prediction accuracies (percent correct)

Model

Structural Accounting Full

Viable farms

Failed farms

91,46

78,95

95,24

Overall

91,46 


\section{REFERENCES}

Adelaja, A.O. and K.B. Rose (1988), "Farm viability revisited: a simultaneous-equation cash flow approach", Agricultural Finance Review, No. 48, pp. 10-24.

Allen, R. (1994), "Farm potential: high tech leads the average farmer's know-how", Texas Banking, Vol. 88, No. 11, pp. 26.

Altman, E.I. (1968), "Financial ratios, discriminant analysis and the prediction of corporate bankruptcy", The Journal of Finance, Vol. XXIII, No. 4, pp. 589-609.

(1993), Corporate Financial Distress and Bankruptcy. A Complete Guide to Predicting and Avoiding Distress and Profiting from Bankruptcy, Wiley \& Sons, New York.

Altman, E.I., R. G. Haldeman and P. Narayanan (1977), "Zeta analysis. A new model to identify bankruptcy risk of corporations", Journal of Banking and Finance. No. 1, pp. 29-54.

Altman, E.I., R.B. Avery, R.A. Eisenbeis and J.F. Sinkey (1981), "Application of classification techniques in business, banking and finance", Contemporary Studies in Economic and Financial Analysis, Vol. 3, pp. 1418.

André, F. (1987), "Vers un renouveau de la formation économique des agriculteurs?", Économie Rurale, No. 177, pp. 53-56.

Bauer, L.L. and J.P. Jordan (1971), "A statistical technique for classifying loan applications", University of Tennesee Agricultural Experiment Statistical Bulletin, No. 476, pp. 1-16.

Beaver, W.H. (1966), "Financial ratios as predictors of failure", Journal of Accounting Research, Supplement, pp. 71111.

Brangeon, J.L., G. Jégouzo and B. Roze (1994), "Les revenus agricoles négatifs", Économie Rurale, No. 224, pp. 3238.

Bronstien, B.F. (1995), "Group seeking to bring more farmers into line on financial reporting", American Banker, november 27 , pp. 8 .

Carley, D.H. and S.M. Fletcher (1988), "Financial soundness of Southern dairy farmers participating in the dairy termination program", Agricultural Finance Review, Vol. 48, pp. 86-93.

Colson, F., A. Blogowski and B. Dorin (1994), "Les exploitations agricoles en situation financière difficile", Revue de Droit Rural. No. 220, pp. 49-56.

Colson, F. and B. Pineau (1991), "Les indicateurs de détection de la difficulté financière des exploitations en période d'installation", Économie Rurale, No. 206, pp. 57-63.

Colwell, M. and R. Koroluk (1990), "Differences in farm incomes using cash or accrual accounting methods on Canadian crop farms and implications for farm management decision making", Canadian Journal of Agricultural Economics, Vol. 38, No. 4, pp. 655-665. 
Cordts, W., K.H. Deerberg and C.H. Hanf (1984), "Analysis of the intrasectorial income differences in West German agriculture", European Review of Agricultural Economics, No. 11, pp. 323-342.

Crabtree, J.R. (1985), "Predicting farm business viability", Farm Management, Vol. 5, No. 8, pp. 325-332.

Crane, L.M. and D.J. Leatham (1995), "External equity financing in agriculture via profit and loss sharing contracts: a proposed financial innovation", Agribusiness, Vol. 11, No. 3, pp. 223-233.

Davies, A.S. (1996), "Insolvency in agriculture: bad managers or Common Agricultural Policy?", Applied Economics, Vol. 28, No. 2, pp. 185-193.

Dunn, D.J. and T.L. Frey (1976), "Discriminant analysis of loans for cash-grain farms", Agricultural Finance Review, № 36, pp. 60-66.

European Commission (1988a), Red de información contable agrícola. Recopilación de: reglamentos, disposiciones de aplicación, informaciones. Fascículo III: la ficha de explotación, Oficina de Publicaciones Oficiales de las Comunidades Europeas, Luxembourg.

(1988b), Définition des variables utilisées dans la présentation des résultats standards du RICA

(niveau 1 et 2), RI/CC 882 rev. 3. Comite Communautaire du Reseau d'Information Comptable Agricole, Brussels.

(1990), Red de información contable agrícola. Vademécum de metodología, Oficina de Publicaciones Oficiales de las Comunidades Europeas, Luxemburg.

(1991a), The Calculation of Economic Indicators Making use of RICA (FADN) Accountancy Data, Office for Official Publications of the European Communities, Luxembourg.

(1991b), Viability of farms, Office for Official Publications of the European Communities, Luxembourg.

(1993), Farm incomes in the European Community in the 1980s, Office for Official Publications of the European Communities, Luxembourg.

(1994a), "EC agricultural policy for the 21st century", European Economy, No. 4, pp. 1-147.

(1994b), The Agricultural Income Situation in Less Favoured Areas of the EC, Office for Official Publications of the European Communities, Luxembourg.

Fennell, R. (1993), "La PAC: asunto sin concluir, problemas sin resolver", Revista de Estudios Agrosociales, No. 165, pp. 39-55.

Foster, W.E. and G.C. Rauser (1991), "Farmer behavior under risk of failure", American Journal of Agricultural Economics, Vol. 73, No. 2, pp. 276-288.

Frydman, H., E.I. Altman and D. KAO (1985), "Introducing recursive partitioning for financial classification: the case of financial distress", The Journal of Finance, Vol. XL, No. 1, pp. 269-291.

Gordon, V.K. and J.P. Arun (1987), "Multivariate normality and forecasting of business bankruptcy", Journal of Business Finance and Accounting, Vol. 4, No. 4, pp. 573-594.

Greene, W.H. (1993), Econometric Analysis, Macmillan, New York.

Griffis, D. (1988), "Classifying farm businesses according to their financial health", Farm Management, Vol. 6, No. 12, pp. 497-503. 
Grisley, W. (1985), "Financial distress on pennsylvania dairy farms", Agricultural Finance Review, No. 45, pp. 1-10.

Harrison A. and R.B. Tranter (1989), The Changing Financial Structure of Farming, Center for Agricultural Strategy, University of Reading.

IASC (1996), A Draft Statement of Principles Issued for Comment by the Steering Committee on Agriculture, IASC, London.

Jacky C.S. (1987), "Some empirical evidence on the outliers and the non-normal distribution of financial ratios", Journal of Business Finance \& Accounting, Vol. 4, No. 4, pp. 483-496.

Johnson, R.B. and A.R. Hagan (1973), "Agricultural loan evaluation with discriminant analysis", Southern Journal of Agricultural Economics, pp. 57-71.

Jolly, R.W., A. Paulsen, K.H. Baum and R. Prescott (1985), "Incidence, intensity and duration of financial stress among farm firms", American Journal of Agricultural Economics, No. 67, pp. 1108-1115.

Jones, F.L. (1987), "Current techniques in bankruptcy prediction", Journal of Accounting Literature, Vol. 6, pp. 131164.

Kauffman, J.B. and L.W. Tauer (1986), "Successful dairy farm management strategies identified by stochastic dominance analyses of farm records". Northeastern Journal of Agricultural and Resource Economics, Vol. 15, No. 168, pp. 168-177.

King, J.S. (1927), Cost Accounting Applied to Agriculture as an Aid to More Productive Farming, Oxford University Press, London, 1927.

Kirton, I. (1997), "Breaking new ground", Accountancy, Vol. 119, No. 1245, pp. 60.

Knopf, E. and R. Schoney (1993), "An evaluation of farm financial benchmarks and loan success/failure: the case of the Agricultural Credit Corporation of Saskatchewan", Canadian Journal of Agricultural Economics, Vol. 41, No. 1, pp. 61-69.

Krause, K.R. and P.L. Williams (1971), "Personality characteristics and successful use of credit by farm families", American Journal of Agricultural Economics, Vol. 53, pp. 619-624.

Kroll, J.C. (1987), "Le nouveau plan comptable: les occasions perdues", Économie Rurale, No. 180, pp. $20-25$.

Laffarga, J. and V. Pina (1995), "La utilidad del análisis multivariante para evaluar la gestión continuada de las empresas", Revista Española de Financiación y Contabilidad, Vol. XXIV, No. 84, pp. 727-748.

Lines, A.E. and M. Morehart (1987), "Financial health of U.S. farm businesses in 1984: a region, type, and size analysis". Agricultural Finance Review, Vol. 47, pp. 43-52.

Lines, A.E. and C.R. Zulauf (1985), "Debt-to-asset ratios of Ohio farmers: a polytomous multivariate logistic regression of associated factors", Agricultural Finance Review, No. 45, pp. 92-99.

Lins, D.A., P.N. Ellinger and D.H. Lattz (1987), "Measurement of financial stress in agriculture", Agricultural Finance Review, Vol. 47, pp. 53-61.

Lo, A.W. (1986), "Logit versus discriminant analysis. A specification test and application to corporate bankruptcies", Journal of Econometrics, Vol. 31, No. 2, pp.151-178. 
Luening, R.A. (1989), "Farm records can improve profitability", in United States Department of Agriculture, (Ed.), Farm Management: How to Achieve your Farm Business Goals, US. Government Printing Office, Washington, pp. 103-112.

Maddala (1989), G.S. Limited-Dependent and Qualitative Variables in Econometrics, Cambridge University Press, Cambridge.

Martin, D. (1977), "Early warning of bank failure", Journal of Banking and Finance, pp. 249-276.

Melichar, E. (1985), Farm Financial Experience and Agricultural Banking Experience, Statement before the Subcommittee on Economic Stabilization of the Committee on Banking, Finance and Urban Affairs, US House of Representatives, Washington DC.

Milhau, J. (1961), Tratado de economía agrícola. Tomo I: los mercados agrícolas y la teoría económica, Bosch Casa Editorial, Barcelona.

Mortensen, T., D.L. Watt and L. Leistritz (1988), "Predicting probability of loan default", Agricultural Finance Review, No. 48, pp. 60-67.

Murdock, S.H. and F.L. Leistritz (1988), The Farm Financial Crisis: Socioeconomic Dimensions and Implications for Producers and Rural Areas, Westview Press, Colorado.

Norussis, M.J. and SPSS Inc. (1990), SPSS/PC+ Advanced Statistics 4.0 for the IBM PC/XT/AT an PS/2, SPSS Inc., Chicago.

Ofek, E. (1993), "Capital structure and firm response to poor performance", Journal of Financial Economics, No. 34, pp. 3-30.

Ohlson, J.A. (1980), "Financial ratios and the probabilistic prediction of bankruptcy", Journal of Accounting Research, Vol. 18, No. 1, pp. 109-131.

Olsson, R. (1988), "Management for success in modern agriculture", European Review of Agricultural Economics, No. 15 , pp. 239-259.

Palepu, K.G. (1986), "Predicting takeover targets. A methodological and empirical analysis", Journal of Accounting and Economics, No. 8, pp. 3-35.

Pederson, G. and C. Donovan (1990), "Credit rating at agricultural banks: Minnesota survey results", Journal of Agricultural Lending, Vol. 3, No. 4, pp. 32-40.

Pellerin, J.L. (1985), "Les agriculteurs et la tenue de la comptabilité", Revue Française de Comptabilité, No. 154, pp. 26-32.

Phimister, E. (1995), "The impact of borrowing constraints on farm households: a life-cycle approach", European Review of Agricultural Economics, No 22, pp. 61-86.

Poppe, K.J. (1991), "Information needs and accounting in agriculture", Agricultural Economics Research Institute LEI, No. 444, pp. 1-51.

Poppe, K.J. and G. Beers (1996), "On Innovation Management in Farm Accountancy Data Networks", Agricultural Economics Research Institute LEI, No. 535, pp. 1-37.

Poppe, K.J. and J.A. Breembroek (1992), "The assessment of a farm's financial situation with a report writer", Tijdschrift voor Sociaalw.onde, Vol. 7, No. 1, pp. 49-70. 
Poppe, K.J. and V. Zachariasse (1986), "Income disparities among farm households and agricultural policy. Case The Netherlands", in European Association for Agricultural Economists (Ed.), Income Disparities among Farm Households and Agricultural Policy, Papers presented to the 14th European Seminar, Rennes, pp. 361-376.

Press, S.J. and S. Wilson (1978), "Choosing between logistic regression and discriminant analysis", Journal of the American Statistical Association, No. 73, pp. 699-705.

Reinsel, E. and J. Brake (1966), "Borrower characteristics related to farm loan repayment", Research Report from the Michigan State University Agricultural Experiment Station East Lansing, No. 59, pp. 1-5.

Richardson, F.M., G.D. Kane and P. Lobingier (1998), "The Impact of Recession on the Prediction of Corporate Failure", Journal of Business Finance \& Accounting, Vol. 25, Nos. 1 \& 2 (Winter), pp. 167-186.

Rodriguez-Vilariño, M.L. (1994a), "Utilidad del análisis de ratios para la predicción de la insolvencia empresarial (I)", Actualidad Financiera, No. 34, pp. C699-C772. (1994b), "Utilidad del análisis de ratios para la predicción de la insolvencia empresarial (III)", Actualidad Financiera, No. 36, pp. C751-C773.

Sabaté, P. and J.P. Enciso (1997) "La valoración de inmobilizados en las empresas agrarias. El caso de las plantaciones", Técnica Contable, No. 579, pp. 177-184.

San Juan, C. (1994), "Crédito innovación y liberalización", Economistas, No. 60, pp. 332-338.

Schmitt, G. (1991), "Why is the agriculture of advanced Western economies still organized by family farms? will this continue to be so in the future?". European Review of Agricultural Economics, No. 18, pp. 443-458.

Seger, D.J. and D.A. Lins (1986), "Cash versus accrual measures of farm income", North Central Journal of Agricultural Economics, Vol. 8, No. 2, pp. 219-226.

Shepard, L.E. and R.A. Collins (1982), "Why do farmers fail? farm bankruptcies 1910-78", American Journal of Agricultural Economics, No. 64, pp. 609-615.

Smale, M., W.E. Saupe and P. Salant (1986), "Farm family characteristics and the viability of farm households in Wisconsin, Mississippi, and Tennessee", Agricultural Economics Research. Vol.38, № 2, pp. 11-27.

Sumpsi, J.M. (1995), "La modernización de la agricultura en España", Revista Española de Economía Agraria, No. 173 , pp. 267-287.

Turvey, C.G. (1991), "Credit scoring for agricultural loans: a review with applications", Agricultural Finance Review, No. 51, pp. 43-54.

Turvey, C.G. and R. Brown (1990), "Credit scoring for a Federal lending institution: the case of Canada's Farm Credit Corporation", Agricultural Finance Review, No. 50, pp. 47-57.

Wadsworth, J.J. and B.E. Bravo-Ureta (1992), "Financial performance of New England dairy farms". Agribusiness, Vol. 8, No. 1, pp. 47-56. 
¡Error! Argumento de modificador desconocido. 
¡Error! Argumento de modificador desconocido. 